\title{
QUESTIONING ECO-THEOLOGICAL PANENTHEISMS: \\ THE PROMISE OF KATHRYN TANNER'S THEOLOGY OF GOD'S RADICAL TRANSCENDENCE FOR ECOLOGICAL THEOLOGY
}

\author{
Hilda P Koster \\ Concordia College of ELCA \\ Moorhead (MN), USA
}

\begin{abstract}
Christian eco-theologians have generally preferred a form of panentheism that plays up divine immanence at the expense of divine transcendence. Yet while their respective theological models have contributed to a more earthly theology, eco-theological panentheists tend to identify God with aspects of creation that are presumably 'more like' God. The latter is problematic in light of their own claim that God is radically present in and to all that is. Drawing on the theology of Kathryn Tanner, this article argues in favour of a different route for maximizing God's immanence, namely by strengthening rather than weakening divine transcendence.
\end{abstract}

Key Words: Eco-theology, Transcendence, Immanence, Panentheism, Kathryn Tanner

Over the last four decades ecological theologians have tirelessly sought to overcome a tendency in Christian theology to cast God's transcendence as distance and God's power as unilateral control, both of which have implicated the doctrine of God in the current global environmental crisis. Because Christians tend to model their own relationship to the world after God's general way of relating to the creation, viewing God as a distant ruler de facto places human beings over and against the rest of nature as its lord and master. This critique was initially voiced by Lynn White Jr. in his 1967 essay "The Historical Roots of the Ecological Crisis." While White's charges have been subject of extensive debate and controversy, they clearly struck a chord with progressive theologians seeking to respond to the ecological crisis. Accordingly, these theologians have by far favoured a panentheistic account of God and world, stressing God's immediate presence in creation and God's power as love. For instance, eco-feminist and process theologies have cast the world as God's body and God as a force present in worldly processes, lovingly luring the world towards perfection. Another group of eco-theologians has proposed a form of panentheism rooted in a social doctrine of the Trinity. While not drawing God and world as close as ecofeminist and process thinkers generally tend to do, these so called Trinitarian panentheists do stress God's presence in creation as Spirit: it is as Spirit that God is continuously creating egalitarian, loving relationship corresponding to the divine community or perichoresis.

Yet while eco-theological panentheisms are to be commended for making Christian theology more earthly, some critics have pointed out that they fail to address the suffering, 
loss and pain integral to natural processes. Lisa Sideris in her 2003 book Environmental Ethics, Ecological Theology, and Natural Selection observes that in their eagerness to overcome the hierarchical dualism of the past, eco-theologians (with the notable exception of process thinkers) have tended to idealize nature's interdependence, obscuring the fact that nature is also random, wasteful, a-moral and violent. ${ }^{2}$ According to Sideris the latter has led to an ill-conceived, sentimentalized environmental ethics, i.e., an ethics based an anthropomorphic notions of what counts as suffering. In a similar vein, Christopher Southgate judges that most eco-theologies avoid the theological questions raised by so called 'natural' evil and, subsequently, neglect to provide an evolutionary theodicy. ${ }^{3}$ While these are important criticisms, I believe that failure to adequately respond to the moral ambiguity of nature is problematic because it undermines eco-theologians own effort to reclaim all of creation as an expression of God. As they stand, eco-theological panentheisms often associate God most closely with those aspects of nature that are either more harmonious, or have a higher capacity for interrelatedness. This raises the question whether God can still be said to be fully present to all that is. For a God who can only be in an intimate relation with what is supposedly most like God is at most partially present in nature.

In light of these concerns, I am proposing a different way of responding to White's critique of Christianity, namely by re-thinking what we mean when we claim that God is transcendent. While most eco-theologians work with a weakened account of divine transcendence, they generally do not step outside the binary opposition of divine transcendence and immanence. Accordingly, divine transcendence continues to have a negative meaning: transcendence mainly serves to prevent drawing God and world too close. ${ }^{4}$ In this article I will explore a different rendering of divine transcendence, a rendering that does not define transcendence in opposition to immanence. To this end I will be drawing on the work of Yale theologian Kathryn Tanner, who has argued that divine transcendence itself indicates that God is beyond all oppositions or contrasts characteristic of created reality. God simply is "not a kind of thing among other kinds of things." According to Tanner, such a non-contrastive account of transcendence does not weaken but strengthen God's presence in and to creation. For only a God who is beyond our categories of being can be

2 Lisa H Sideris, Environmental Ethics, Ecological Theology, and Natural Selection (New York: Columbia University Press, 2003).

3 Cf. Christopher Southgate, The Groaning of Creation: God, Evolution, and the Problem of Evil (Louisville: Westminster John Knox Press, 2008).

4 Not all ecological theologians have responded to White Jr.'s critique of Christianity by way of a negative assessment of divine transcendence. For instance, Denis Edwards maintains a strong notion of God's transcendence, while developing a theology of divine action that respects the autonomy of created causes. Drawing on Thomas Aquinas' account of secondary causes, Edwards defends a non-interventionist account of the way God acts in the world, i.e., God acts in the world in and through the laws and contingencies of the natural world. When motivating this theological turn, he cites his commitment to an understanding of divine transcendence that is rooted in the apophatic tradition by stressing both the radical mystery of God and the limitations of our knowledge of things divine. Cf. Denis Edwards How God Acts: Creation, Redemption and Special Divine Action (Minneapolis, MN: Fortress Press, 2010), Chapter 3. Ernst Conradie insists that there is need for a renewed appreciation of divine transcendence in ecological theology, in particular when it comes to respecting the freedom of creation. While he acknowledges that certain accounts of divine transcendence have led to an Adeist separation and alienation between God and creation, he urges ecological theologians to come up with a robust account of divine transcendence that articulates God's otherness without removing God from the world. Ernst Conradie, Christianity and Ecological Theology: Resources for Further Research (Stellenbosch, South-Africa: Sun PreSS, 2006:99-100.

5 Kathryn E Tanner, Jesus, Humanity and the Trinity: A Brief Systematic Theology (Minneapolis: Fortress Press, 2001:4. 
said to be close to things that are not like God at all. In other words, the world does not need to resemble God in order to be an expression of God.

My aim in this article is subsequently to demonstrate the promise of Tanner's notion of divine transcendence for articulating God's radical presence in the world. The first part of the article fleshes out the problems I see with eco-theological panentheism by discussing the social Trinitarian model of Jürgen Moltmann and the process theology of John Cobb Jr. While very different, both these theologies risk weakening their account of God's presence in nature by associating God with certain aspects of reality that are assumed to be more like God. The second part of the article discusses Tanner's non-contrastive notion of divine transcendence, which she culls from early Christian debates on the immanence and transcendence of God against the background Hellenistic accounts of divinity. While my discussion of Tanner's study of these early debates seeks to elaborate on her concept of God's non-contrastive transcendence, it also sheds additional light on the current conundrum of eco-theological panentheism. The conclusion of the article draws out the promises of Tanner's non-contrastive account of divine transcendence for an ecological theology and ethics.

\section{Two Examples of Eco-Theological Panentheisms}

As a first step I will take a closer look at the panentheism of Jürgen Moltmann. Moltmann's social doctrine of the Trinity has provided eco-theologians with a prominent, early paradigm for 'greening' God's relationship to the world. According to Moltmann, God can be said to be present in the world as Spirit: the world is created in and through the Spirit and it is as Spirit that God dwells in creation. ${ }^{6}$ This account of the Spirit is anchored within Moltmann's social doctrine of the Trinity, which secures his panentheism. The reasoning is as follows: because all three persons of the Trinity dwell in each other in a reciprocal and mutual manner, all persons participate equally in the divine rule. Accordingly, Moltmann can claim that the immanent Spirit is not a watered down version of the divine: as the divine Spirit, God is truly and fully present in the world. At the same time, however, the social doctrine of the Trinity preserves the transcendence of God's Spirit. As an equal member of the Trinity, God's Spirit can never be fully equated with the world and its processes. The social Trinity thus allows Moltmann to stress the immanent-transcendence of God.

The problem with Moltmann's panentheistic scheme for an ecological theology is not that he insists on preserving divine transcendence as such. Rather the problem is that he ends up suggesting that only those aspects of creation that correspond to the perfect divine perichoresis express God's presence most fully. Or, so it seems is the implication of the following statement: "Our starting point here is that all relationships which are analogous to God reflect the primal, reciprocal indwelling and mutual interpenetration of the Trinitarian perichoresis." ${ }^{7}$ As it stands, however, relationships in nature are, as a rule, not reciprocal and mutual in the way Moltmann portrays the Trinity. In nature there is predation and parasitism, which, while necessary for survival, are not equally benefiting the individual creatures

\footnotetext{
6 "From the continual inflow of the divine Spirit (ruach) created things are formed (bara). They exist in the Spirit, and they are renewed through the spirit. This presupposes that God always creates through and in the power of his Spirit, and that the presence of his Spirit therefore conditions the potentiality and realities of his creation. The further assumption is that his Spirit is poured out on everything that exists, and that the Spirit preserves it, makes it live and renews it." Jürgen Moltmann, God in Creation: A New Theology of Creation and the Spirit of God. $1^{\text {st }}$ US ed., The Gifford Lectures 1984-1985 (San Francisco: Harper \& Row, 1985$), 10$.

7 Ibid., 17.
} 
involved. Moltmann undercuts this criticism in two ways. First of all, as Sideris has insightfully pointed out, he operates with an account of ecological space in which each organism has its allotted space or niche, guaranteeing it its own food supply. While Moltmann acknowledges that there is predation, and hence suffering in nature, adaptation safeguards abundance for all. In the real world, however, adaptation involves natural selection. Instead of perfect adaptation, natural selection assumes that "there is genetic variation which is random in that it is not oriented to an adaptive outcome." Acting upon this random variation, those variants that are advantageous in the context of a particular environment are preserved. Accordingly, adaptation includes waste and the elimination of the 'unfit.' As Sideris sees it, Moltmann chooses "to collapse variation and selection into a single force that continually guides evolution towards adaptation." 9 Building on this misguided notion of nature, he assumes that the Spirit of God acts to overcome suffering and struggle in nature associated with selection, while creating and maintaining community and adaptation.

Moltmann's second solution to the reality of suffering in nature, then, is that he casts God's Spirit first and foremost as the eschatological Spirit. As the eschatological Spirit, God suffers the world's contradictions, while pointing ahead towards God's eschatological future; a future in which death will be overcome and God will finally fully dwell in creation. The implication here is that only a nature redeemed from the forces of natural selection can hold the divine. It is important to note, moreover, that Moltmann insists that even in the eschaton the world is still finite. While death will be overcome, the world does not become infinite. It is only in this ideal finite world, then, that God will be All in All. ${ }^{10}$ Needless to say that since an immortal but finite world will never be realized in our reality, God may very well never be fully present in nature as we know it. When all is said and done, Moltmann's theology can at most affirm God's presence in nature in a provisionary way. Ultimately, God's indwelling is an eschatological ideal. ${ }^{11}$

Unlike Moltmann's Trinitarian panentheism process theology provides a much more satisfying theological treatment of the evolutionary character of nature. In what follows I will focus mainly on the process theology of John Cobb Jr., who was the first to spell out the potential of process theology for an ecological theology. ${ }^{12}$ Following Whitehead's

Sideris, Environmental Ethics, Ecological Theology and Natural Selection, 101.

Ibid.

10 Cf. Moltmann, God in Creation, 98-104.

11 The problems with Moltmann's panentheism are reiterated by his interpretation of creatio ex nihilo.

Moltmann reads the divine act of creating out of nothing as an act of kenosis, or divine self-limitation. When creating the world, God first withdraws God-self so as to allow for a space in which a non-divine world can come into existence. Moltmann equates the space resulting from God's self-limitation with absolute nothingness. God then can be said to create ex nihilo in that God calls the world into being within the space in which God is not. Instead of an expression of God's abundance, creation is characterized by the absence of God construed as loss: in the beginning there is not fullness of being, but loss of God's presence. Cf. Moltmann, God in Creation, 87-93.

12 For Cobb's introduction to process theology, see John Cobb, Jr. and David Ray Griffin. Process Theology: An Introductory Exposition (Louisville, KY: Westminster John Knox Press, 1976). Cobb's work on ecological theology started as early as 1972 by way of his little book Is it Too Late? A Theology of Ecology (Beverly Hills, CA: Bruce, 1972). Cobb's initial interest in the environmental crisis was prompted by his reading of Paul. R Ehrlich's book The Population Bomb (New York: Ballantine Books, 1968), which opened his eyes to the fundamental threat modern ways of living posed to the ecological basis of sustainable life. Sparked further by Lynn White Jr.'s accusation of Christianity's role in the environmental crisis, Cobb began to see process thought as a way to 'a new Christianity:' a Christianity no longer plagued by a dichotomy between humanity and nature. In another pioneering work The Liberation of Life: From the Cell to the Community (Cambridge: Cambridge University Press, 1981), which he co-authored with the Australian biologist Charles Birch, Cobb explored the connection between process theology and evolutionary biology. 
process metaphysics, Cobb's process theology understands the world as being essentially relational and dynamic. The world is constantly in the process of moving towards greater complexity. An increase in complexity involves both an increase in the possibility of enjoyment and an increase in disorder and strife, and hence, suffering. Indeed, it is one of the central insights of process metaphysics that complexity, enjoyment and discord are correlated. Within this picture of the nature of reality, God is understood as 'the creative aim' or 'lure' persuading the world towards higher levels of self-actualization. While God's lure seeks to avoid as much discord as possible, God works in and with all forces of life, including those of natural selection. Yet, in order not to equate God with the world's creativity (which Whitehead himself tended to do), Cobb also cast God's lure as the divine Agape, or God's responsive love. As divine Agape God receives what the world has become in responsive to God's creative love or Eros. In other words, while process theology draws God and world close, they are not the same.

Process theology's panentheism is persuasive, of course, only in so far as one accepts process metaphysics as the main interpretative grid for a theological understanding of reality. Another much rehearsed criticism of process theology is that it reduces God to a cause among other causes: while God is at work in every actual occasion luring it towards greater self-realization, God is not the only force determining the outcome. Within process theology this is first and foremost a statement about God's power. Process theology criticizes traditional accounts of divine transcendence for casting God's power as domination or coercion. Yet while I too do not wish to reiterate oppressive accounts of divine sovereignty, it seems to me that process theology's rendering of the divine lure risks weakening God's presence in creation. For saying that the world's processes are determined by forces operating in tandem and even in competition with the divine lure entails that God is not fully constitutive of all that is. Process theology does insist, however, that the world's increasing complexity enables a greater self-actualization of God within the world. This idea of God's own 'becoming' allows for a more radical account of God's presence over time. Yet pairing God's self-actualization with an increase in complexity does seem to entail that God is more present in and to forms of life with more complex self-actualization. The latter is problematic not just for what it implies about the fullness of God's presence, but also from the perspective of ecology. After all, there is no reason to suppose that more complex forms of life are the ones whose representation in nature is most important for the preservation of an eco-system. Less complex forms of life may have little richness of experience, they are crucial to the health and continuation of an eco-system. Thus while an eco-theology may not want to deny that God is present differently in a human than say in a fish, it does want affirm that both express the divine fullness equally. Like Moltmann's theology, then, Cobb's panentheism falls short when it comes to articulating that God is present in all of creation in an equally direct and intimate manner. In spite of his positive embrace of discord and suffering as part of the reality of nature, Cobb identifies God most closely to what is presumed to be most like God: complex forms of consciousness.

\section{Kathryn Tanner's Radical or Non-Contrastive Account of Divine Transcendence}

Against the background of the shortcomings of Cobb's process theology and Moltmann's Trinitarian theology, I have been looking for a different way to relate God and world and have found Tanner's notion of non-contrastive transcendence to be extremely helpful. The overall drift of Tanner's theology is that creation is to be affirmed as God's gift. Taking her clue from the event of Jesus Christ, Tanner proposes that we view creation retrospectively 
as the expression of God's ongoing gift-giving: God gives to the world its very existence from the fullness of God's own life. As Tanner sees it, God created the world for the sole purpose of communicating God's own being and goodness to it, albeit in a finite shape. And because a finite world cannot receive all God wants to give it at once, God bestows God's gifts in stages, over time. Creation, covenant and salvation must all be seen as stages or degrees, "representing a greater communication of goodness to the creature and the overcoming of any sinful opposition to these gifts' distribution." ${ }^{13}$ Thus God's ongoing gift-giving brings the world into a more loving, transforming union with God.

Tanner insists that God's ongoing gift-giving does not need to come either at the expense of the world's autonomy, or at the expense of God's presence and power. This is the case because of two interrelated principles that are central to her theology, namely the principle of God's radical transcendence and the principle of a non-competitive relationship between God and world. As I already indicated Tanner's principle of God's radical transcendence signifies that God is not a kind of thing among other kinds of things. God simply cannot be captured by our categories of being. The second principle - that of a noncompetitive relationship between God and world - flows from this interpretation of divine transcendence. A God who is beyond kinds, never is in competition with creatures with regard to their ability to act or operate on their own: "the creature does not decrease so that God may increase." ${ }^{14}$ Viewing God as the fecund provider of all that a creature is in itself simply does not take away from a creature's character as a created being.

Tanner develops these two principles by looking at debates about God and world in the early Church against the backdrop of Hellenistic dilemmas concerning divinity. According to Tanner early Christian theologians came to defend a non-contrastive or radical account of God's transcendence precisely because they sought to make sense of the seemingly contradictory claim that God is both transcendent and directly involved with the world - a claim which became really significant in the context of Christological debates on the divinity and humanity of Christ. She explains that within the Greco-Roman world God was either a thing among other things found in the world, or God was utterly different from anything in the world. Both claims (Tanner calls them 'horns') of this so called GrecoRoman dilemma assume that like must be involved with like. ${ }^{15}$ If unlike things are intimately involved with each other - for instance, an eternal principle with a finite world their respective natures are compromised. Thus the first horn of the Greco-Roman dilemma simply gives certain things within the world divine status. For instance, in the rational theologies of Plato, the Stoics, and Aristotle divinity at times is "a general set of qualities eternality, rationality, order, simplicity, unity - in which a number of things can participate in differing degrees." 16 In other words, divinity is "a class name, a sortal term, specifying those principles within the world that are responsible for order, pattern and regularity." 17 Accordingly, many things can be called divine, either within this finite world (e.g., numbers and eternal truths), or outside it (e.g., the cosmos, heavenly bodies). Divinity simply is a predicate determined by commonality and susceptible to difference. ${ }^{18}$

Tanner, Jesus, Humanity, and the Trinity, 2.

Ibid.

A quote from Tanner's (unpublished) paper "Creation as Mixed Metaphor" which was presented at the Transdisciplinary Colloquium at Drew University (2001). Tanner's account of the Greco-Roman dilemma can also be found in God in Creation in Christian Theology: Tyranny or Empowerment? (New York: Blackwell, 1988), 39-44.

16 Tanner, "Creation as Mixed Metaphor," 4.

17 Ibid.

18 Ibid., 5. 
The second horn of the Greco-Roman dilemma constructs divinity in radical opposition to anything in the world and casts transcendence as distance. The rationale here is that because like can be only involved with like, God cannot have anything directly to do with a finite world of death and decay. This tendency is at work especially in the religious cosmologies of Middle Platonism (second and third centuries CE). These cosmologies assume "a supremely transcendent divine principle or high God," which is usually a combination of Aristotle's unmoved mover, Plato's discussion of the Good in the Republic, and some metaphysical suggestions about a supreme principal of unity in Plato's Parmenides. ${ }^{19}$ This high God relates to the world from afar and indirectly. In order not to be tainted by a material world, the supreme God produces a chain of intermediary divine principles, which form a kind of 'buffer zone' between God and world.

It is interesting to pause here for a moment and consider how both these options within the Hellenistic argument over divinity are reiterated by the eco-theological debate on God's presence in the world. On the one hand, eco-theologians reject a contrastive account of God because it encourages a hierarchical account of God and world. On the other hand, they risk identifying certain things in the world as a more adequate representation of the divine. Somehow we still seem to be moving within the field of possibilities set out by the GrecoRoman dilemma. According to Tanner, however, the theologians of the early Church rejected both solutions to the Greco-Roman dilemma and were attracted, instead, to the neo-Platonism of Plotinus (205-270 CE). According to Plotinus, the first God simply is not a particular sort of thing that stands in contrast to other sort of things: God is neither like nor unlike anything in the world. ${ }^{20}$ Plotinus developed this non-contrastive account of divine transcendence by drawing out Plato's Idea of the Good in the Republic as "the unparticipated ground of all Being and Knowing beyond any distinction between Being and Becoming, Pure Forms and the physical world." ${ }^{21}$ In Tanner's analysis, Plotinus' account of divinity has three important implications: first, because the first principle is beyond all contrasts, it no longer only produces what is most like it. Second, because the first God is not like anything in the world, God's productive capacity is no longer restricted. Whereas a first God who is a kind of thing can only produce what is most like itself, a God beyond kinds can be the source of all that is. Finally, Tanner judges that Plotinus' account of the first God's relation to the world implies that divine transcendence no longer means distance. $^{22}$ For in order to be separate from something one needs to have a difference in itself - a difference that implies one is something in contrast to something else. Obviously, a God who is beyond being does not contain such a difference. Accordingly, God cannot be separated from anything.

Plotinus then demonstrates that when God is seen as beyond any of the contrasts that characterize finite being, God can be intimately involved with all that is in a comprehensive manner. Unfortunately, as Tanner observes, Plotinus himself is not fully consistent in following through on this insight. According to his scheme of being, the first principle is directly involved only with the production of what is most like itself: the mind. Plotinus further situates the One over and against the multiple. He suggests that somehow the divine is ultimately not "beyond the contrast between the one and the multiple, but becomes a thing among others - that kind of thing that is one rather than internally divided." 23 This

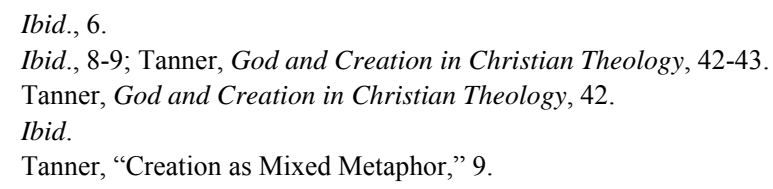


implies that everything that is characterized by multiplicity and difference - i.e. finite existence - cannot be fully present to the divine. In Plotinus, finite being can only reach unity with the One by leaving our multiplicity and difference behind: we need to become like the divine in order to be present to it.

Unlike Plotinus himself, however, early Christian theologians did realize that "Hellenistic ideas about God's radical transcendence suggest that ... God is intimately involved with everything." ${ }^{24}$ According to Tanner this is the point of Ireneaus' polemic with the Gnostics. Ireneaus argues that if the first God is indeed fullness without limit - as the Gnostics claimed - than nothing can be outside the direct influence of this God: there simply is "nothing that exists apart from God and nothing that is not subject to God's direct influence." 25 God is not at a distance from the world, but is immediately and intimately present to all that is. Indeed, Ireneaus claims that because divine transcendence is beyond "all oppositional contrasts characteristic of the relations among finite beings," God also exceeds the duality between presence and absence. Accordingly, divine transcendence "allows for the immanent presence to creatures of God in his otherness." 66

According to Tanner then it is precisely because Ireneaus defends a non-contrastive account of divine transcendence that he is able to assure "God's direct and intimate relation with every creature in the entirety of its physical and particular being." 27 It is important to note that Tanner's assessment of Ireneaus differs from that of some eco-theologians, most notably Catherine Keller. While Keller recognizes Ireneaus' achievement and commends him for insisting that God is immediately involved with all that is, she holds him responsible for solidifying the idea of an omnipotent Creator. To Keller's mind, Ireneaus' "hands-on immediacy strengthens the imaginary of unilateral, linear and masculine dominance," which she believes comes at the expense of finite contingency. ${ }^{28}$ Keller's criticism is an important reminder of the continued need for a hermeneutics of suspicion when reading Christianity's early texts. For even when Ireneaus' intentions might not have been to install a dominative theology, his account of a God who creates ex nihilo has certainly fed into oppressive accounts of God and world. Nonetheless, Tanner's analysis demonstrates that God's immediacy does not have to come at the expense of the autonomy of finite creatures. As long as Ireneaus' account of God's relation with the world is situated within the overall context of his non-contrastive account of divine transcendence, God's presence can never be in competition with created existence: created existence simply does not decrease when God's presence or agency increases.

In sum, then, Tanner demonstrates, first of all, that early Christian thinkers preferred a non-contrastive form of transcendence which viewed God as beyond the distinctions and contrasts characteristic of ordinary categories of being. Instead of suggesting God's distance from creation, such an account of transcendence allowed these early theologians to claim that God is directly and intimately present to all that is without endangering the

\footnotetext{
24 Ibid.; Tanner, God and Creation in Christian Theology, 56. In both cases Tanner refers to the second book of Ireneaus: Against Heresies.

25 Tanner, "Creation as Mixed Metaphor," 10.

26 Tanner, God and Creation in Christian Theology, 57 (my emphasis).

27 Ibid., 56. The latter was extremely relevant in light of Christological debates on the relationship between divinity and humanity in Christ. The theologians of the early church sought to maintain that the one and only highest God is fully present in the human Jesus without compromising the divinity of God or the humanity of Jesus. Cf. Tanner, "Is God in Charge? Creation and Providence." In Essentials of Christian Theology, edited by William C. Placher, (Louisville, KY: Westminster John Knox Press, 2003), 116-130.

28 Catherine Keller, Face of the Deep: A Theology of Becoming (New York, NY: Routledge, 2003) 51.
} 
creature's own agency and dignity of being. Because a God who is beyond kinds is not in competition with creatures when it comes to their ability to act and operate on their own, the freedom and quality of being of the creature is not compromised when brought into close relation with the divine. Hence Tanner claims that instead of promoting a hierarchical and dualistic cosmology, early Christian theology seemed to have utilized the notion of God's transcendence to block such an account.

\section{Promises for an Eco-Theological Account of God and World}

In conclusion I wish to draw out four further promises of Tanner's reading of divine transcendence for ecological debates on God and world. First of all, Tanner's work allows for a much more positive account of divine transcendence within eco-theological discourse. Within eco-theological panentheisms divine transcendence patrols the boundary between God and world. While God and world are drawn close, reiterating God's transcendence serves to ensure that they are not the same. According to Tanner's reading of transcendence, however, divine transcendence does not curtail God's presence in creation, but makes it possible for us to claim God's boundless presence in and to the world. Tanner's way of conceptualizing God as being beyond the binary categories of closeness and distance thus resolves the uneasy truce between divine immanence and divine transcendence characteristic of eco-theological panentheism.

Secondly, Tanner's notion of God's radical transcendence allows ecological theology to be more consistently non-anthropocentric and non-hierarchical. ${ }^{29}$ Because God is beyond the distinctions and contrasts characteristic of ordinary categories of being, God can be said to be present to all of created existence in an equally direct and intimate manner. While a mosquito may express the fullness of God's super-abundance in a different way than a human being, this says nothing whatsoever about God's presence to it. And while it may be true that higher grades of life experience God's presence more intensely, this too does not mean that God is present to it in a way different than God can be said to be present to a lower form of life.

Tanner's notion of divine transcendence is promising also because it does not seem to lead to the theodicy conundrum. Affirming the world as God's good creation no longer needs to be at odds with the violence, death and decay intrinsic to nature. For claiming that God is radically transcendent allows us to see the world as the perfect, yet finite expression of God's superabundance. Natural selection and variation are not an anomaly or the expression of the threat of nothingness. They are part and parcel of the fabric of a good, but finite world. Yet in so far more violent forces of life hinder the full expression of God (for instance because of excessive suffering and the ability to anticipate pain) God works to overcome these forces by drawing the world closer to God. This is the point of Tanner's theology of God's ongoing gift-giving. Over time, the world is able to receive God's superabundance more fully by being drawn closer to God. This does not need to mean, however, that the world becomes divine. Rather it means that the world becomes more fully itself. Closeness to God does not eliminate the world's own being as a finite creation. On the contrary, the closer the world is to God the better the world operates according to its own principles.

This inference has been made by Tanner herself as well. See Tanner, "Creation, Environmental Crisis, and Ecological Justice.” In Reconstructing Christian Theology, edited by Rebecca S Chopp and Mark Lewis Taylor, (Minneapolis: Fortress Press, 1994:99-123. 
This leads me to my fourth and final point, Tanner's notion of God's transcendence helps eco-theologians retrieve a sense of God's creative power as constitutive of created existence, a notion that gets lost in process theology. Because God's power is not in competition with created causality, eco-theologians can affirm God as the source (or giver) of all that a creature is in itself, without being worried that this will take away from the creature's own power and agency. Claiming that God's power is constitutive of created existence does not mean that creatures are passive. God's creative power simply does not come at the expense of the active operations of a created cause. What this means also is that the binary opposition between bad and good power - the power of control versus the power of love - does not apply when talking about God. Because God's agency is comprehensive and immediate, God does not work from the outside to redirect or manipulate the conduct of others, as ordinary forces do. While there are certainly many bad forms of power, God's way with the world simply is not like any of our ways in the world.

\section{REFERENCES}

Edwards, Denis 2010. How God Acts: Creation, Redemption and Special Divine Action. Minneapolis, MN: Fortress Press.

Cobb Jr. John 1972. Is It Too Late? A Theology of Ecology. Beverly Hills, CA: Bruce.

Cobb, Jr. John and David Ray Griffin 1976. Process Theology: An Introductory Exposition. Louisville, KY: Westminster John Knox Press.

Cobb, Jr., John, and Charles Birch 1981. The Liberation of Life: From the Cell to the Community. Cambridge: Cambridge University Press.

Conradie, Ernst 2006. Christianity and Ecological Theology: Resources for Further Research. Stellenbosch, South Africa: Sun Press.

Keller, Catherine 2003. Face of the Deep: A Theology of Becoming. New York: Routledge. Moltmann, Jürgen 1985. God in Creation: A New Theology of Creation and the Spirit of God. 1st U.S. ed., The Gifford Lectures 1984-1985. San Francisco: Harper \& Row. Sideris, Lisa H 2003. Environmental Ethics, Ecological Theology and Natural Selection. New York: Columbia University Press.

Southgate, Christopher 2008. The Groaning of Creation: God, Evolution, and the Problem of Evil. Louisville: Westminster John Knox Press.

Tanner, Kathryn E 1988. God and Creation in Christian Theology: Tyranny or Empowerment? New York: Blackwell.

1985. "Creation, Environmental Crisis, and Ecological Justice." In

Reconstructing Christian Theology, edited by Rebecca S. Chopp and Mark Lewis

Taylor, 99-123. Minneapolis: Fortress Press.

2001. Jesus, Humanity, and the Trinity: A Brief Systematic Theology.

Minneapolis: Fortress Press.

2001. "Creation as Mixed Metaphor." Paper presented at the Trans-disciplinary

Theological Colloquium, Drew University.

2003. "Is God in Charge? Creation and Providence." In Essentials of Christian

Theology, edited by William C Placher, 116-30. Louisville, KY: Westminster John Knox Press.

White Jr., Lynn 1976. "The Historical Roots of Our Ecological Crisis." Science 155. 1203-7. 